3-бөлім

Механика

IRSTI 30.15 .15
Раздел 3

Section 3

Механика

Mechanics

DOI: https://doi.org/10.26577/JMMCS.2021.v112.i4.05

\author{
T.M. Ospan* A.B. Kydyrbekuly , G.E. Ibrayev \\ al-Farabi Kazakh National University, Kazakhstan, Almaty \\ *e-mail: ospan.tm@gmail.com
}

\title{
RESONANT PHENOMENA IN NONLINEAR VERTICAL ROTOR SYSTEMS
}

In this paper, the study of the dynamics of a rotor system mounted on an elastic foundation rotating in rolling bearings is considered. To describe the bearing model, the Hertz theory was used, linking radial loads acting on the bearing and deformation at the points of contact between the movable foundation and the bearing rings. In the bearing model, it is assumed that there are no types of sliding of bodies and rolling surfaces. The obtained differential equations of the rotor and the foundation do not have a common solution. Therefore, the study was conducted using numerical methods. In order to simplify the problem and increase the accuracy in solving the obtained differential equations, dimensionless quantities were used. With the increase and decrease of dimensionless quantities, the amplitudes of the rotor and the foundation are constructed. As a result, two resonances were formed: the main resonance and the second resonance. The work is connected with the physical meaning of the process considered in the problem the results obtained are the basis for the application of this mathematical model in the design of a rotary system rotating in rolling bearings.

Key words: Hertz theory, rolling bearings, numerical methods, "rotor-foundation" system, nonlinear rotary system.

$$
\begin{gathered}
\text { Т.М. Оспан*, А.Б. Қыдырбекұлы, Г.Е. Ибраев } \\
\text { әл-Фараби атындағы Қазақ ұлттық университеті, Қазақстан, Алматы қ. } \\
\text { *e-mail: ospan.tm@gmail.com } \\
\text { Бейсызық роторлық жүйелердеги резонанстық құбылыстар }
\end{gathered}
$$

Бұл жұмыста домалау мойынтіректерінде айналатын серпімді негізге орнатылған ротор жүйесінің динамикасын зерттеу қарастырылады. Мойынтірек моделін сипаттау үшін Герцті мойынтірекке әсер ететін радиалды жүктемелерді байланыстыратын теориясы және жылжымалы негіз мен мойынтірек сақиналары арасындағы байланыс нүктелеріндегі деформация қолданылды. Мойынтірек моделінде жылжымалы денелер мен жылжымалы беттер жоқ деп болжанады. Алынған ротор мен фундаменттің дифференциалдық теңдеулерінде ортақ шешім жоқ. Сондықтан зерттеу сандық әдістерді қолдану арқылы жүргізілді. Есепті жеңілдету және алынған дифференциалдық теңдеулерді шешудің дәлдігін арттыру үшін өлшемсіз шамалар қолданылды. Өлшемсіз шамалардың ұлғаюымен және азаюымен қозғалтқыш пен фундаменттің амплитудасы құрылады. Нәтижесінде екі резонанс пайда болды: бас резонанс және екінші резонанс. Жұмыс тапсырмада қарастырылған процестің физикалық мағынасымен байланысты. Алынған нәтижелер осы математикалық модельді домалау мойынтіректерінде айналатын роторлы жүйені жобалау кезінде қолдануға негіз болып табылады.

Түйін сөздер: Герц теориясы, домалау мойынтіректері, сандық әдістер, "ротор-фундамент" жүйесі, бейсызық роторлық жүйе.

Т.М. Оспан*, А.Б. Қыдырбекұлы, Г.Е. Ибраев

Казахский национальный университет им. Аль-Фараби, Казахстан, г. Алматы

*e-mail: ospan.tm@gmail.com

Резонансные явления в нелинейных вертикальных роторных системах 
В данной работе рассматривается исследование динамики роторной системы, установленной на упругом основании, вращающемся в подшипниках качения. Для описания модели подшипника использовалась теория Герца, связывающая радиальные нагрузки, действующие на подшипник, и деформацию в точках контакта между подвижным основанием и кольцами подшипника. В модели подшипника предполагается, что не существует типов скольжения тел и поверхностей качения. Полученные дифференциальные уравнения ротора и фундамента не имеют общего решения. Поэтому исследование проводилось с использованием численных методов. Для упрощения задачи и повышения точности решения полученных дифференциальных уравнений использовались безразмерные величины. С увеличением и уменьшением безразмерных величин строятся амплитуды двигателя и фундамента. В результате образовались два резонанса: главный резонанс и второй резонанс. Работа связана с физическим смыслом рассматриваемого в задаче процесса. Полученные результаты являются основой для применения данной математической модели при проектировании вращающейся системы, вращающейся в подшипниках качения.

Ключевые слова: теория Герца, подшипники качения, численные методы, система "роторфундамент" , нелинейная роторная система.

\section{Introduction}

Currently, most of the rotary machines used in industry, manufacturing and mechanical engineering rotate in rolling bearings [1]. As a mathematical model of rolling bearings, it is important to choose models that most fully reflect the features of rolling bearings, in particular, such as the number of holes, the influence of geometric errors, as well as the properties of nonlinear stiffness; the influence of centrifugal forces, mutual displacement and mismatch of bearing rings; gyroscopic phenomena [2].

In the proposed work, the nonlinear dynamics of a rotor system mounted on an elastic foundation rotating in rolling bearings is investigated. Due to the increased requirements for the accuracy of rotation and an increase in the speed of rotation of the rotors, it becomes necessary to take into account the elastic nonlinear properties of rolling bearings.

\section{Review}

Currently, rotating machines, widely used in industry, mainly work with rolling bearings $[3$ and [4]. The use of rolling bearings as supports for high-speed rotors is limited by their speed and strength, therefore, sliding bearings are widely used to ensure reliable rotation of the rotor in a wide range of speeds and loads. These bearings have smaller dimensions in the radial direction, greater rigidity, low sensitivity to shocks and temporary loads, unlike rolling bearings, which makes them suitable for use in high-speed turbomachines.

According to the number of rotor supports, the turbomachine layout schemes used can be two- and three-support. Three-support rotor schemes are used in rare cases when a twosupport scheme leads to an unacceptably large decrease in the bending stiffness of the rotor. The use of a three-support circuit makes the rotor statically indeterminate, which makes it difficult to assemble the turbomachine due to the difficulty of ensuring an accurate fit of the rotor in the foundation on three surfaces [5].

Also, for the most complete description of the process, it is important to take into account the influence of factors such as imbalance, asymmetry of the rotor installation on the shaft, external friction, changes in inertial parameters and positional forces of various kinds [6]- 8]. 
Such complications of the model in the analysis of dynamics make it possible to investigate the effect of the gap size, rotation frequency on the frequency spectra and amplitude-frequency characteristics for any rotary system on rolling bearings.

Mathematical models of bearings that take into account non-linearity factors are distinguished by complexity and, first of all, by the loads they take into account. In our case, the Hertz contact theory is used to describe the bearing model, which relates radial loads acting on the bearing and deformation at the points of contact between the rolling body and the bearing rings [9]. When describing the bearing model, it is assumed that there are no any types of slippage of rolling bodies and surfaces. Damping is considered in the formulation of equivalent viscous and linear friction.

\section{Problem statement and equation of motion}

Consider a vertical rotary system (Fig. 1). The damping foundation on elastic supports moves in a horizontal plane. The rotor has a static imbalance. The rotor performs a plane-parallel motion, and rotation around the coordinate axes does not occur. The motion of the rotor and the foundation is considered relative to the fixed coordinate system of the $O x y$. The nonlinear regenerative force of the bearing is described as (1) in accordance with the Hertz contact theory.

$$
F_{C}=C_{b} \delta_{r}^{\frac{3}{2}}
$$

where $F_{C}$ is a component of the restoring force in the radial direction $(N), \delta_{r}$ is the deformation in the radial direction $(m), C_{b}$ is the stiffness coefficient $\left(\frac{N}{m}{ }^{\frac{3}{2}}\right)$.

In order to solve the equations of motion of the system and qualitative analysis, the restoring force of a bearing of type (1) can be approximated by a degree series of type (2) in accordance with [10], 13]:

$$
F_{C}=c_{0} \delta_{r}+c_{1} \delta_{r}^{3}
$$

where $c_{0}$ and $c_{1}$ are stiffness coefficients for the linear and cubic terms, respectively. This expansion for $\delta_{r}<1000 \mu m$ with a sufficient degree of accuracy is in agreement with the experiments 13$]$.

The geometric coordinates of the rotor center are denoted by $O_{1}\left(x_{1}, y_{1}\right)$, and its center of mass is denoted by $O_{s}(x, y)$. The center of mass of the foundation is $O_{2}\left(x_{2}, y_{2}\right)$ (Fig.1).

The kinetic energy of the system is defined as (3) :

$$
U=\frac{m}{2}\left(x^{\prime 2}+y^{\prime 2}\right)+\frac{J}{2} \Omega_{0}^{2}+\frac{M}{2}\left(x_{1}^{\prime 2}+y_{1}^{\prime 2}\right)
$$

where $m$ is the mass of the rotor, $J$ is the moment of polar inertia of the rotor, and $M$ is the mass of the foundation.

Considering that the potential energy of the isotropic elastic nonlinear field of rolling bearings depends on the radially directed deformation of rolling bearings, that is

$$
\delta_{r}^{2}=\left(x_{1}-x_{2}\right)^{2}+\left(y_{1}-y_{2}\right)^{2}
$$


Where is the potential energy of rolling bearings and elastic supports:

$$
\left.W=\frac{c_{2}}{2}\left(x_{2}^{2}+y_{2}^{2}\right)^{2}+\frac{c_{0}}{2}\left(\left(x_{1}-x_{2}\right)^{2}+\left(y_{1}-y_{2}\right)^{2}\right)+\frac{c_{1}}{4}\left(\left(x_{1}-x_{2}\right)^{4}+\left(y_{1}-y_{2}\right)^{4}\right)\right)+\ldots
$$

Accordingly, the dissipation function:

$$
R=\frac{\chi}{2}\left(x^{\prime 2}+y^{\prime 2}\right)+\frac{\chi_{0}}{2}\left(x_{2}^{\prime 2}+y_{2}^{\prime 2}\right)
$$

The center of mass of the rotor relative to a fixed coordinate system is determined as follows:

$$
x=x_{1}+e \cos \Omega_{0} t, y=y_{1}+e \sin \Omega_{0} t .
$$

where $e$ is the magnitude of the deviation of the center of mass of the rotor from the geometric center.

The equation of motion of the system has the form (8)

$$
\left\{\begin{array}{l}
m \frac{d^{2} x_{1}}{d t^{2}}+c_{0}\left(x_{1}-x_{2}\right)+c_{1}\left(x_{1}-x_{2}\right)^{3}+\chi \frac{d x_{1}}{d t}=m e \Omega_{0}^{2} \cos \Omega_{0} t, \\
m \frac{d^{2} y_{1}}{d t^{2}}+c_{0}\left(y_{1}-y_{2}\right)+c_{1}\left(y_{1}-y_{2}\right)^{3}+\chi \frac{d y_{1}}{d t}=m e \Omega_{0}^{2} \sin \Omega_{0} t, \\
M \frac{d^{2} x_{2}}{d t^{2}}+c_{2} x_{2}-c_{0}\left(x_{1}-x_{2}\right)-c_{1}\left(x_{1}-x_{2}\right)^{3}+\chi_{0} \frac{d x_{2}}{d t}=0, \\
M \frac{d^{2} y_{2}}{d t^{2}}+c_{2} y_{2}-c_{0}\left(y_{1}-y_{2}\right)-c_{1}\left(y_{1}-y_{2}\right)^{3}+\chi_{0} \frac{d y_{2}}{d t}=0, \\
x_{1}(0)=e, \quad x_{2}(0)=0.1 e, \quad y_{1}(0)=0, \quad y_{2}(0)=0, \\
\left.\frac{d x_{1}}{d t}\right|_{t=0}=0,\left.\frac{d x_{2}}{d t}\right|_{t=0}=0,\left.\frac{d y_{1}}{d t}\right|_{t=0}=0,\left.\frac{d y_{2}}{d t}\right|_{t=0}=0,
\end{array}\right.
$$

(8) - a system of equations describes the movement of the rotor and the foundation on unbalanced, nonlinear supports.

We reduce the system of equations (8) to a system of dimensionless equations of the form (9), i.e

$$
\left\{\begin{array}{l}
\frac{d^{2} f_{1}}{d \tau^{2}}+2 \zeta_{1} \frac{d f_{1}}{d \tau}+\left(f_{1}-f_{2}\right)+\varepsilon\left(f_{1}-f_{2}\right)^{3}=\eta^{2} \cos (\eta \tau), \\
\frac{d^{2} \nu_{1}}{d \tau^{2}}+2 \zeta_{1} \frac{d \nu_{1}}{d \tau}+\left(\nu_{1}-\nu_{2}\right)+\varepsilon\left(\nu_{1}-\nu_{2}\right)^{3}=\eta^{2} \sin (\eta \tau), \\
\frac{d^{2} f_{2}}{d \tau^{2}}+2 \mu \zeta_{2} \frac{d f_{2}}{d \tau}-\mu\left(f_{1}-f_{2}\right)-\mu \varepsilon\left(f_{1}-f_{2}\right)^{3}+\mu \lambda f_{2}=0 \\
\frac{d^{2} \nu_{2}}{d \tau^{2}}+2 \mu \zeta_{2} \frac{d \nu_{2}}{d \tau}-\mu\left(\nu_{1}-\nu_{2}\right)-\mu \varepsilon\left(\nu_{1}-\nu_{2}\right)^{3}+\mu \lambda \nu_{2}=0
\end{array}\right.
$$

where,

$$
\begin{gathered}
x_{1}=e f_{1}, x_{2}=e f_{2}, y_{1}=e \nu_{1}, y_{2}=e \nu_{2}, \\
\mu=\frac{m}{M}, \omega_{1}^{2}=\frac{c_{0}}{m}, \omega_{2}^{2}=\frac{c_{2}}{m}, \tau=\omega_{1} t, \Omega_{0}=\omega_{1} \eta, \\
\zeta_{1}=\frac{\chi}{2 m \omega_{1}}, \zeta_{2}=\frac{\chi_{0}}{2 m \omega_{1}}, \varepsilon=\frac{c_{1} e^{2}}{m \omega_{1}^{2}}, \lambda=\frac{\omega_{2}^{2}}{\omega_{1}^{2}} .
\end{gathered}
$$

We introduce complex variables in the form (10)

$$
z_{1}=f_{1}+i \nu_{1}, z_{2}=f_{2}+i \nu_{2}
$$




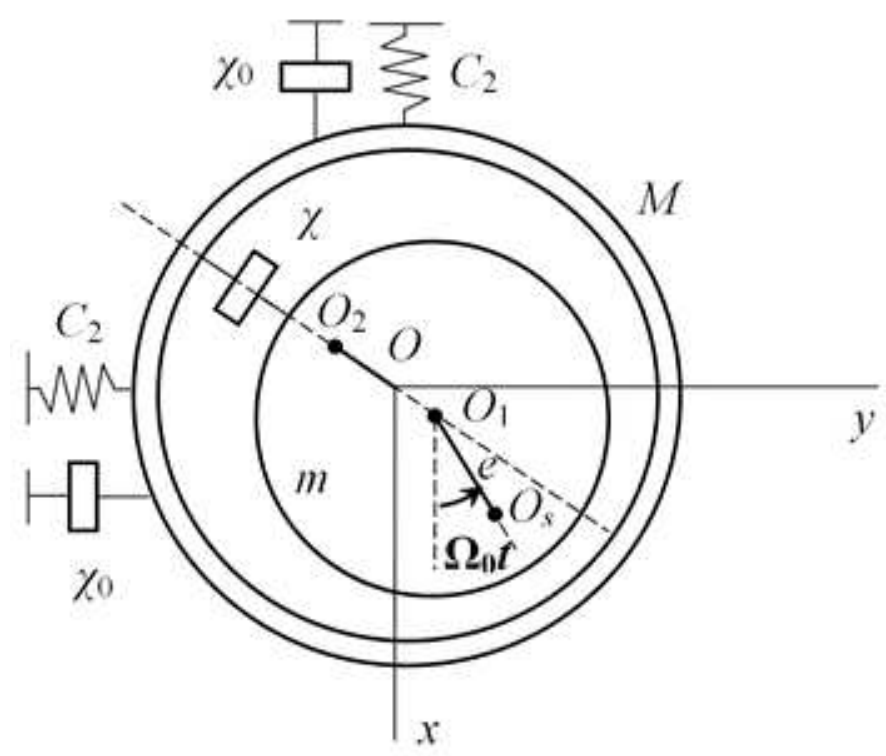

Figure 1: Vertical rotor system.

Then, given (10) from (9), we write the equation of motion in the complex plane in the form (11).

$$
\left\{\begin{array}{l}
z_{1}^{\prime \prime}+\left(z_{1}-z_{2}\right)+\varepsilon\left(z_{1}-z_{2}\right)^{3}+2 \zeta_{1} z_{1}^{\prime}=\eta^{2} e^{i \eta \tau} \\
z_{2}^{\prime \prime}+\mu \lambda z_{2}-\mu\left(z_{1}-z_{2}\right)-\mu \varepsilon\left(z_{1}-z_{2}\right)^{3}+2 \mu \zeta_{2} z_{2}^{\prime}=0 .
\end{array}\right.
$$

The approximated solution of the system of equations (11) can be searched analytically.

$$
\begin{aligned}
& z_{1}=A_{1} e^{-i \eta \tau}+B_{1} e^{-2 i \eta \tau}+\ldots, \\
& z_{2}=A_{2} e^{-i \eta \tau}+B_{2} e^{-2 i \eta \tau}+\ldots
\end{aligned}
$$

Studies in this direction can be found in the works [11], [12]. The parametric analysis of a given rotor system in the presented work is based on the results of numerical methods.

\section{Results and discussion}

In Figure 2, there is one resonance and one autotherm zone. In the case of a head resonance, i.e., at $\eta=1.49, f_{1}=1.789523788$ is equal to when the rotor amplitude $\mu=10$. For the rotor, the autothermic zone is generally observed in the range of $0.01<\eta<0.99$. In this case, $f_{1}=0.364555924$, when the maximum amplitude of the rotor is $\mu=10$. With a decrease in the mass of the foundation, the value of the amplitudes of the rotor and the autotherm of the foundation decreases to $35-50 \%$. With an increase in $\mu$, there is a shift of the head resonance to the right in the direction of frequency growth and an increase in the autothermic zone. A 
decrease in the mass of the foundation and the movement of the rotor and the foundation in the reverse phase in this interval leads to the disconnection of the autotherms.

In Figure 3, the region of bass resonance and autotherms is observed at low frequencies and occurs in a wide range of ?. In the case of a general resonance, i.e. at $\eta=1.13, f_{2}=$ 0.809546423 is equal to when the amplitude of the base $\mu=5$ at $\mu=10$, there is a shift of the head resonance to the right in the direction of frequency growth. If the mass of the foundation decreases, i.e. the value $\mu$ increases, then the amplitude of the rotor increases during the head resonance, and vice versa, if the value $\mu$ decreases, the area of autotherms and leads to the attenuation of the head resonance.

In Figure 4, two resonances occur. At the head nonlinear resonance, i.e. $\eta=1.13$, the rotor amplitude is equal to $f_{1}=1.382985602$ for $\varepsilon=1$. The second (left) resonance is observed in the range of $0.01<\eta<0.32$. In this case, the rotor amplitude at all values of $\varepsilon$ is $f_{1}=0.080489253$. When the rigidity of the rotor decreases, the value of the left resonant amplitudes of the rotor and the foundation becomes the same. At $\varepsilon=50$, the amplitude of the rotor reaches $f_{1}=2.146287817$, at $\eta=1.77$, there is a break in the amplitudes, and at $\eta>1.77$, the amplitude values decrease sharply. At $\varepsilon=100$, the rotor amplitude is equal to $f_{1}=3.372849069$, and there is a shift of the head resonance to the right in the direction of frequency growth. If the rigidity of the rotor decreases, i.e. the value of $\varepsilon$ decreases, then the value of the resonant amplitudes on the left will have the same value, and vice versa, if the value of $\varepsilon$ increases, the amplitude of the rotor at the head resonance will increase.

In Figure 5, there is a general resonance. At the main resonance, i.e. $\eta=1.21, f_{2}=$ 0.130031134 , when the amplitude of the base is $\varepsilon=2$. At $\varepsilon=50$, the amplitude of the foundation is equal to $f_{2}=0.182760123$. At $\varepsilon=50$, the amplitude of the foundation reaches $f_{2}=0.19322489$, at $\eta=1.73$, there is a break in the amplitudes, and at $\eta>1.73$, the amplitude values decrease sharply. At $\varepsilon=100$, the amplitude of the base is equal to $f_{2}=$ 0.343379276 , and there is a shift of the head resonance to the right in the direction of frequency growth. If the value $\varepsilon$ increases during the head resonance, then the rotor amplitude increases and there is a shift of the head resonance to the right in the direction of frequency increase.

In Figure 6, two resonances occur. At the head resonance, i.e. $\eta=1.2$, the rotor amplitude $\lambda=1$ is equal to $f_{1}=1.38132898$. The second (left) resonance is observed in the range of $0.01<\eta<0.52$. In this case, the value $f_{1}=0.201216136$ when the rotor amplitude is $\lambda=10$. With a decrease in the rigidity of the foundation, the value of the left resonant amplitudes of the rotor and the foundation decreases to $15-20 \%$, but at $\lambda=0.1$, the left resonant amplitude is equal to $f_{1}=0.231227653$. If the rigidity of the foundation decreases, i.e. the value $\lambda$ decreases, then the value of the resonant amplitudes on the left decreases, and vice versa, if the value $\lambda$ increases, then the amplitude of the rotor at the head resonance will have the same value.

In Figure 7, one resonance occurs. The second (left) resonance is observed in the range of $0.01<\eta<0.35$. In this case, when the amplitude of the foundation is $\lambda=10, f_{2}=$ 0.203282867 . With a decrease in the rigidity of the Foundation, the value of the left resonant amplitudes of the rotor and the foundation decreases to $10-37 \%$, but at $\lambda=0.1$, the left resonant amplitude is equal to $f_{2}=0.243458891$. If the hardness of the foundation decreases, i.e. the value $\lambda$ decreases (except $\lambda=0.1$ ), then the value of the left resonance amplitudes decreases, and vice versa, if the value $\lambda$ increases, this leads to a head resonance shutdown.

In Figure 8, two resonances occur. At the head resonance, i.e. $\eta=1.26, f_{1}=9.182929085$ 
is equal to when the rotor amplitude is $\zeta_{1}=0.1$. The second (left) resonance is observed in the range of $0.01<\eta<0.15$. In this case, $f_{1}=0.306469753$ is equal to when the rotor amplitude is $\zeta_{1}=0.2$. With a decrease in the internal coefficient of friction, the value of the left resonant amplitudes of the rotor and the foundation increases to $30-45 \%$. With an increase in the coefficient of internal friction, i.e. when $\zeta_{1}>2$, the zone of autotherms and leads to the deactivation of the head resonance. If the internal coefficient of friction decreases, i.e. the value of $\zeta_{1}$ increases, then this leads to a shutdown of the left and head resonance, and vice versa, if the value of $\zeta_{1}$ decreases, the amplitude of the rotor at the head resonance increases.

In Figure 9, two resonances occur. At the main resonance, i.e. $\eta=1.26, f_{2}=1.022983788$, when the amplitude of the base is $\zeta_{1}=0.1$. The second (left) resonance is observed in the range of $0.01<\eta<0.35$. In this case, at $\zeta_{1}=0.1$, the amplitude of the foundation is equal to $f_{2}=0.53389977$. With a decrease in the internal coefficient of friction, the value of the left resonant amplitudes of the rotor and the foundation increases to $40-60 \%$ at $\zeta_{1}<1$. With an increase in the coefficient of internal friction, i.e. when $\zeta_{1}>2$, it leads to the attenuation of the head resonance. If the internal coefficient of friction decreases, i.e. the value of $\zeta_{1}$ increases, then this leads to a shutdown of the head resonance, and vice versa, if the value of $\zeta_{1}$ decreases, the amplitude of the rotor at the head resonance increases.

If the external coefficient of friction $\zeta_{2}$ decreases or increases, then the value of the amplitudes of the rotor and the foundation at the head resonance will have the same value.

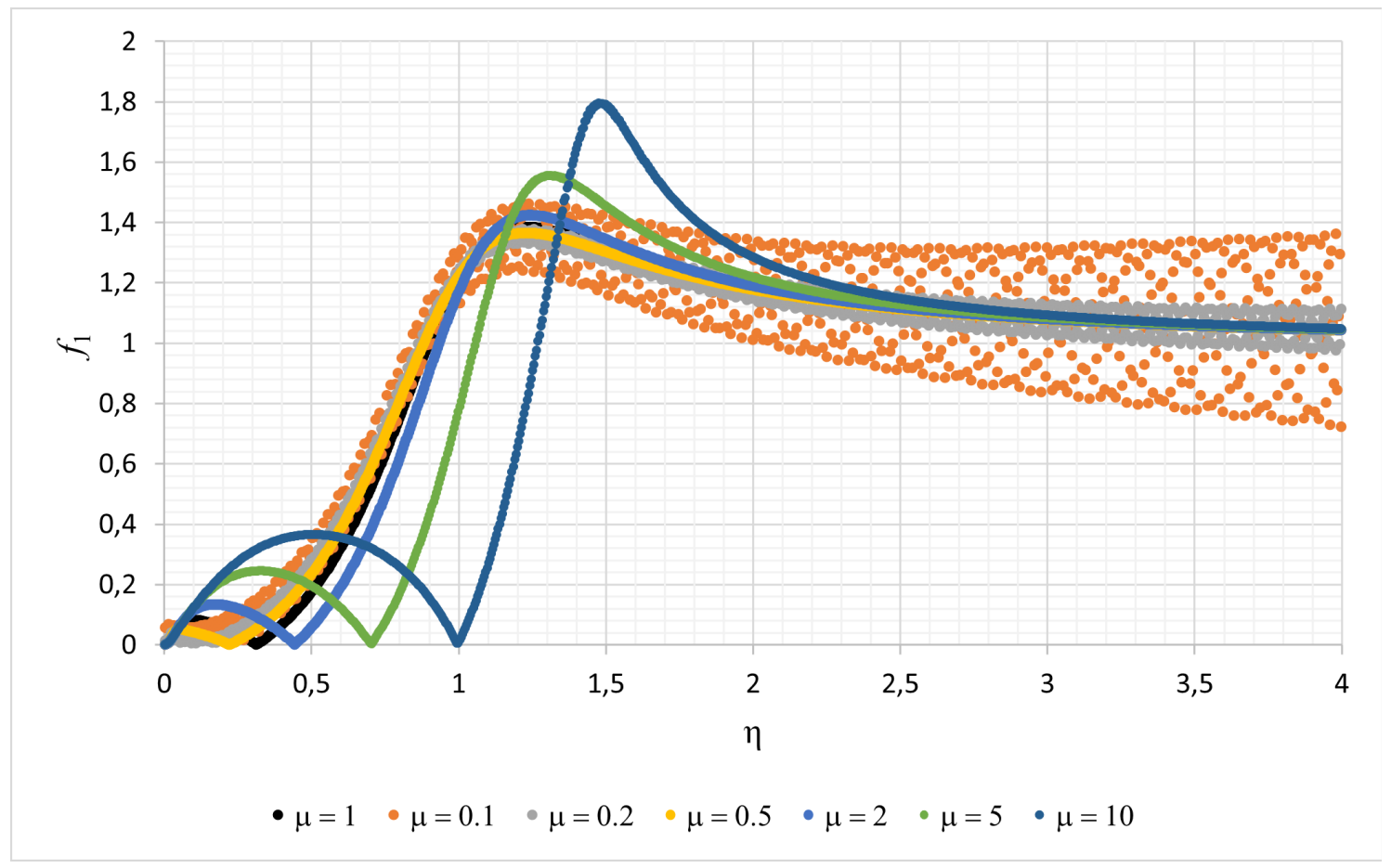

Figure 2: The amplitude of the rotor at different values of the ratio of the mass of the rotor and the foundation $-\mu$. 


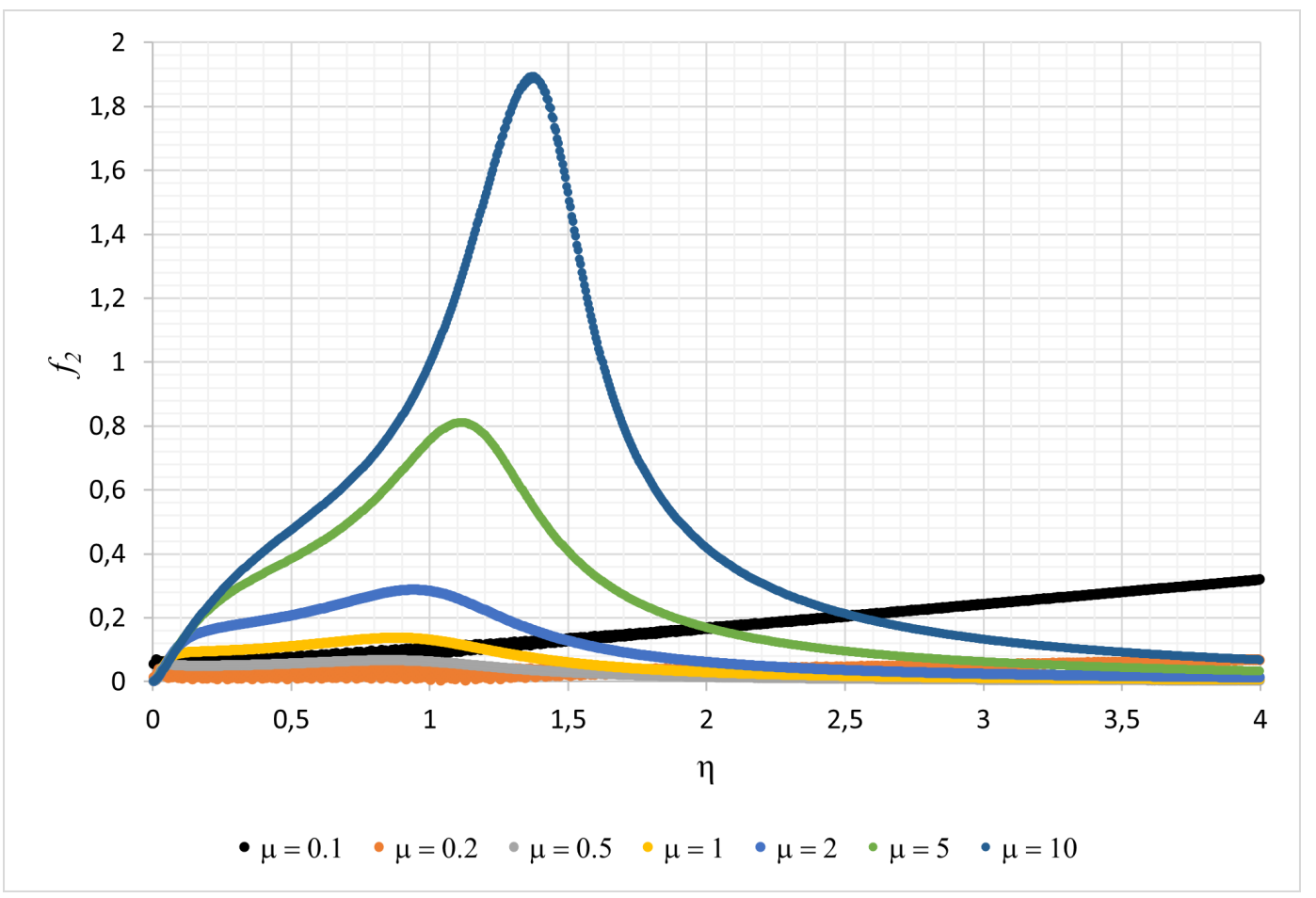

Figure 3: The amplitude of the foundation at different values of the ratio of the mass of the rotor and the foundation $-\mu$.

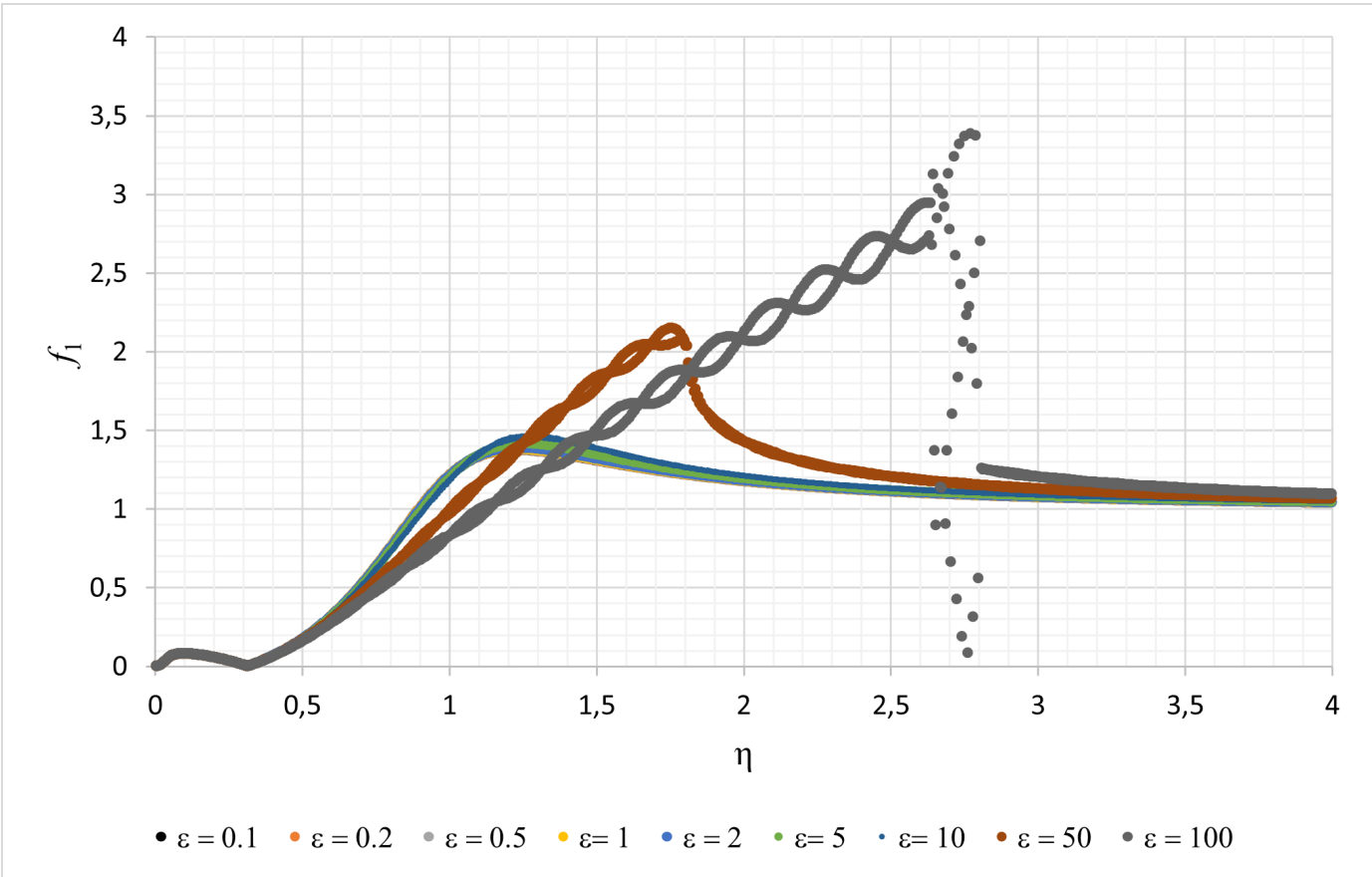

Figure 4: The amplitude of the rotor at different values of the stiffness of the rotor $-\varepsilon$. 


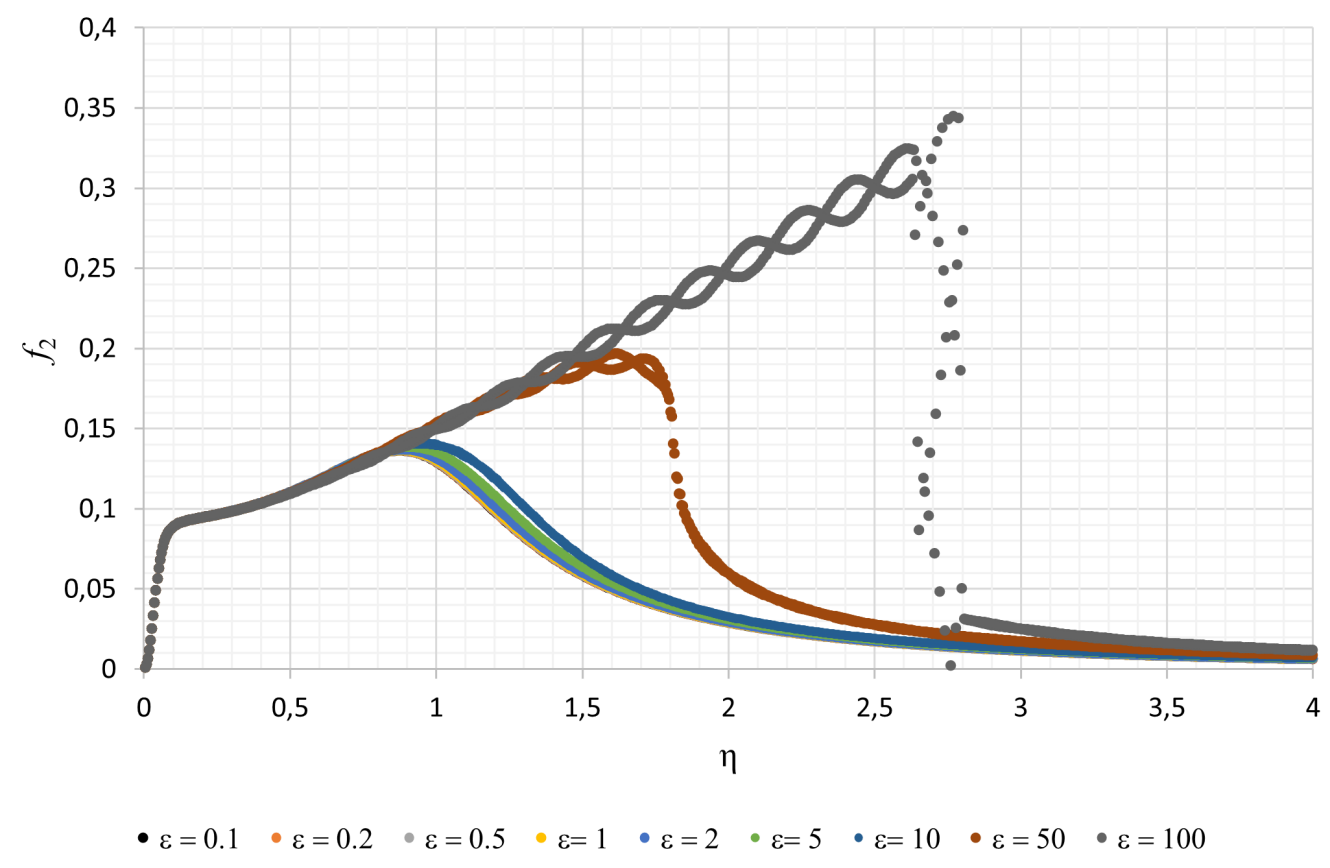

Figure 5: The amplitude of the foundation at different values of the stiffness of the rotor $-\varepsilon$.

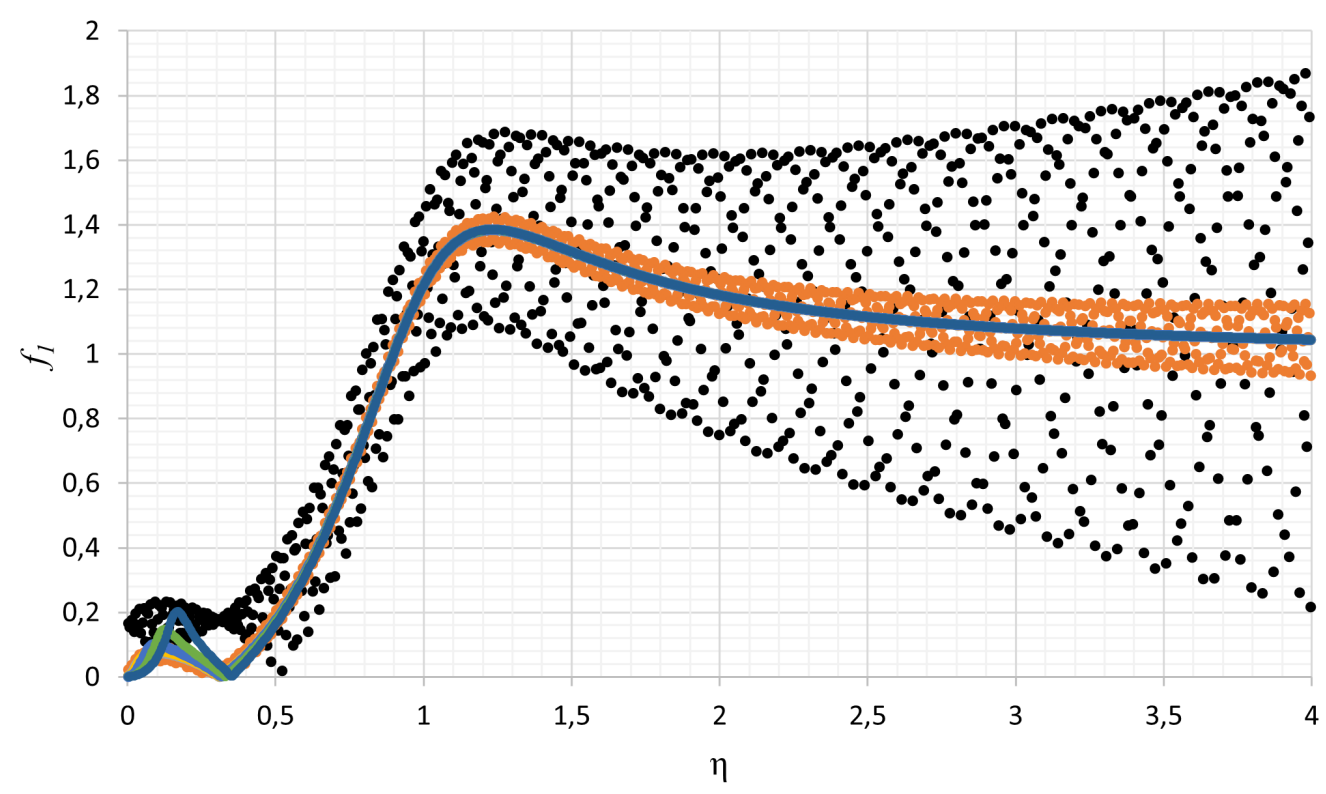

$\bullet \lambda=0.1 \cdot \lambda=0.2 \cdot \lambda=0.5 \cdot \lambda=1 \cdot \lambda=2 \cdot \lambda=5 \cdot \lambda=10$

Figure 6: The amplitude of the rotor at different values of the rigidity of the foundation $-\lambda$. 


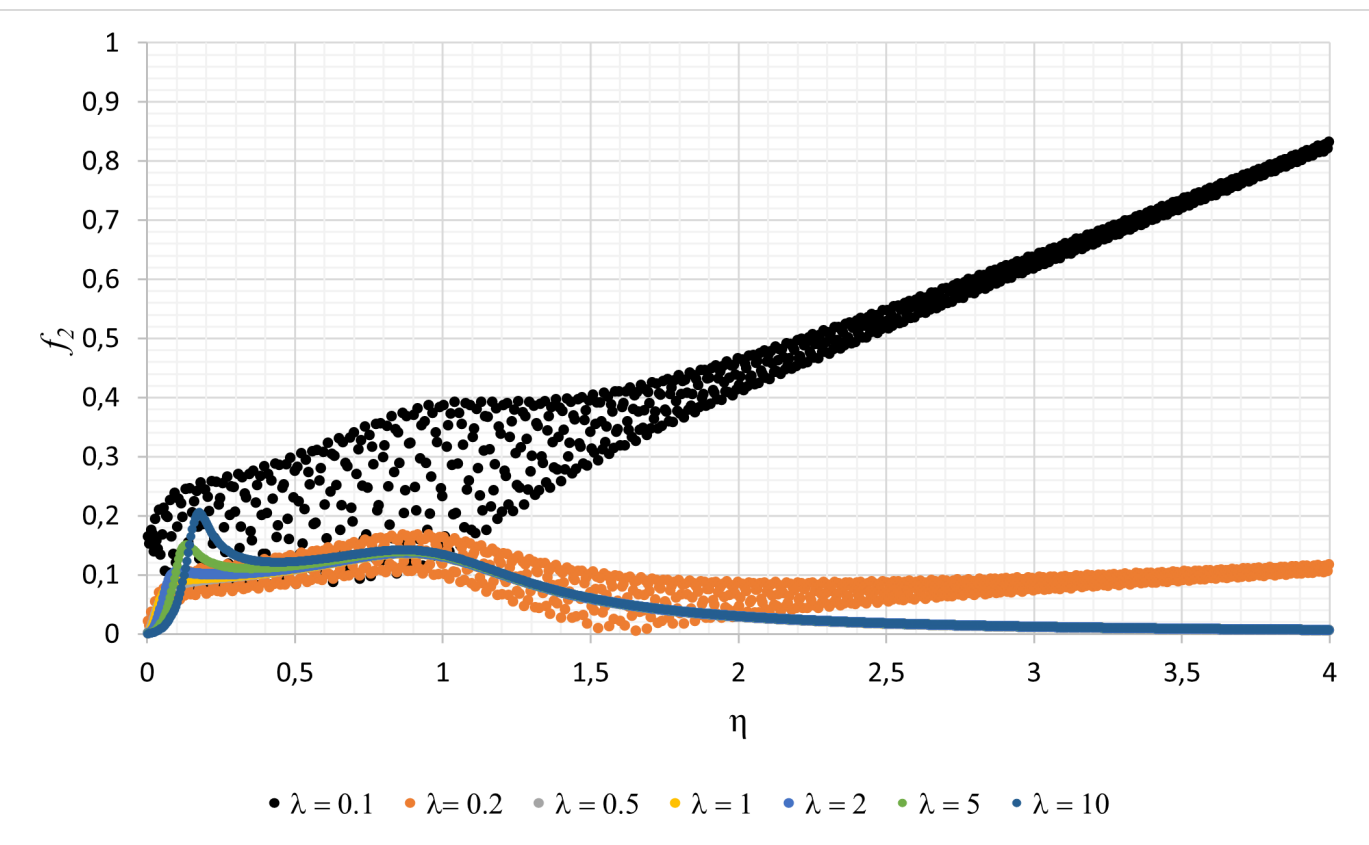

Figure 7: The amplitude of the foundation at different values of the rigidity of the foundation $-\lambda$.

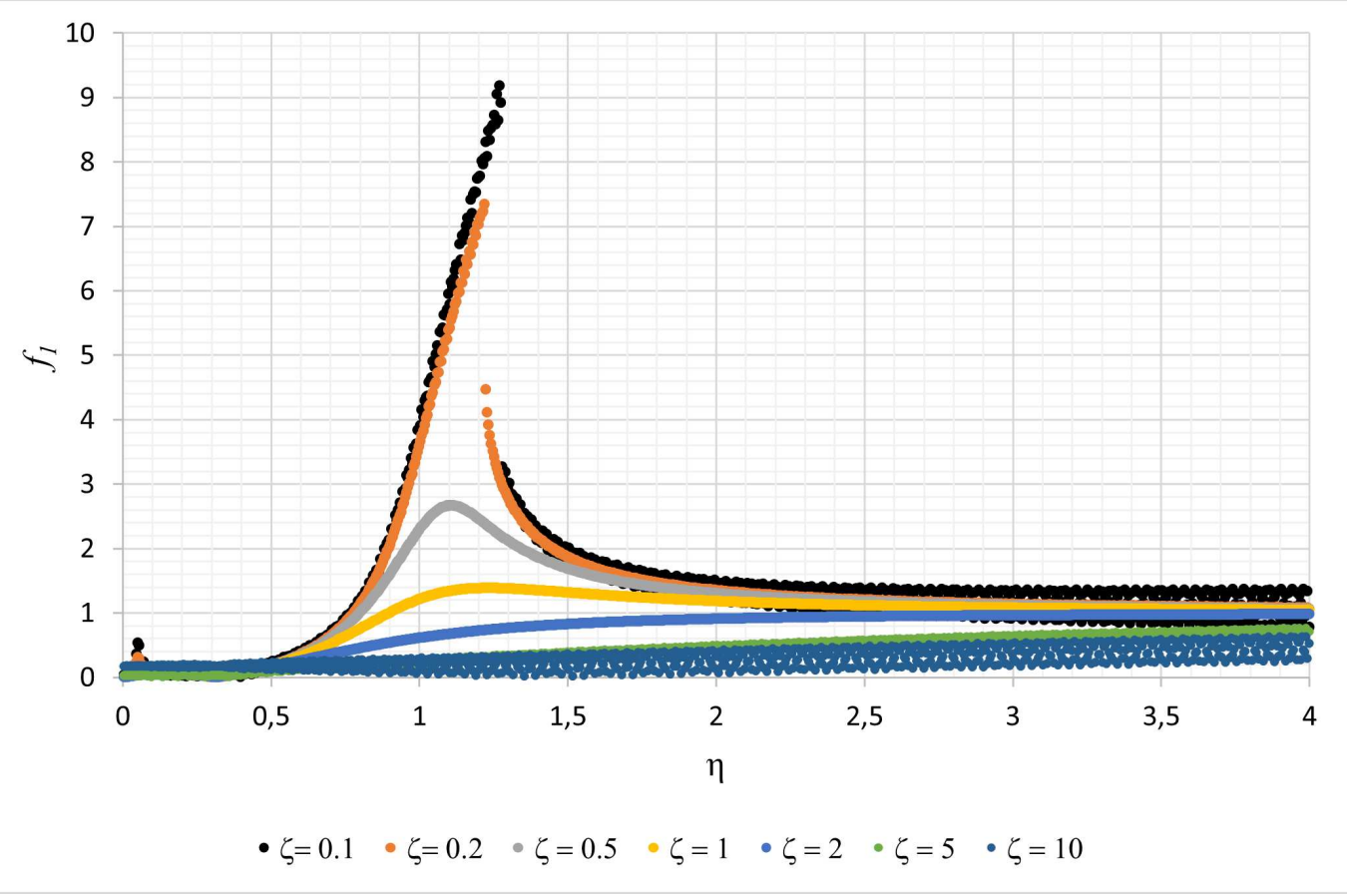

Figure 8: The amplitude of the rotor at different values of the coefficient of internal friction $-\zeta$. 


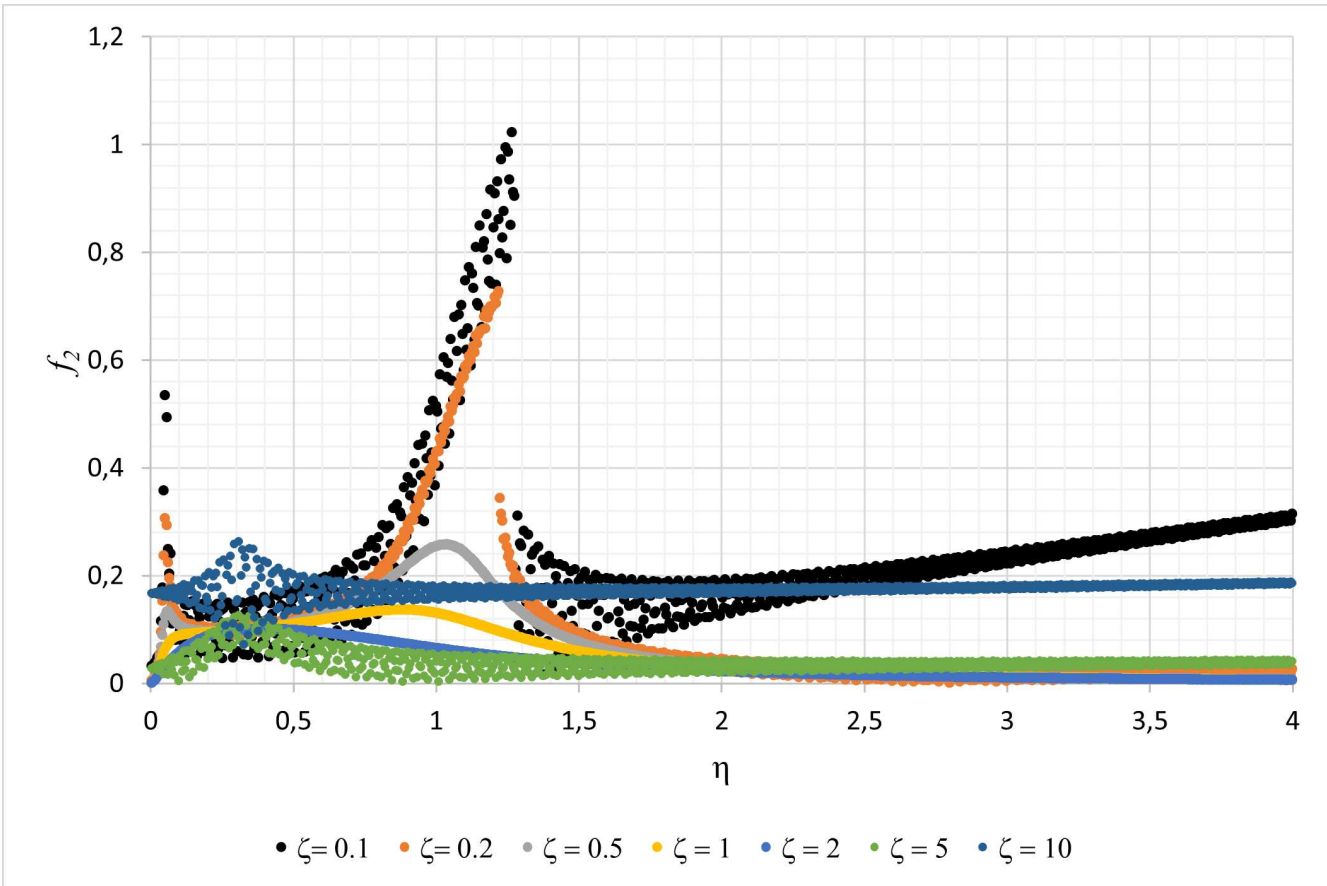

Figure 9: The amplitude of the foundation at different values of the coefficient of internal friction $-\zeta$.

\section{Conclusion}

In this paper, a generalized dynamic model of the "rotor-foundation" system on elastic supports has been developed, the description of which is nonlinear. A method for determining the amplitude of forced oscillations of the system has been developed. The resonant frequencies are determined, as well as the frequency range in which the answering machines occur. The features of the coupled "rotor-foundation" system are shown when taking into account the movement of the foundation. The values of the coefficients of imbalance, foundation mass, stiffness and damping, providing optimal values of amplitudes, are determined. The results of the work performed prove the physical meaning of the task, and this, in turn, can serve as the basis for the introduction and application of this mathematical model in production. Disabling dangerous rotor vibrations by selecting system parameters is cost-effective and technically easy. The results of the work make it possible to conduct engineering and computational experiments with minimal costs, give qualitative and quantitative characteristics and reduce the design time of new vertical rotary machines, improve the quality and safety of their work.

\section{Acknowledgements}

This work has been supported financially by the research project AP08856167 of the Ministry of Education and Science of the Republic of Kazakhstan and was performed at Research Institute of Mathematics and Mechanics in Al-Farabi Kazakh National University, which is 
gratefully acknowledged by the authors.

\section{References}

[1] Sharma A., Upadhyay N., Kankar P.K., Amarnath M., "Nonlinear dynamic investigations on rolling element bearings: A review", Advances in Mechanical Engineering, 10 (3) (2018): 1-15. DOI: 10.1177/1687814018764148.

[2] Li Z., Li J., Li M., "Nonlinear dynamics of unsymmetrical rotor-bearing system with fault of parallel misalignment" , Advances in Mechanical Engineering, 10(5) (2018): 1-17. DOI: 10.1177/1687814018772908.

[3] Sun L., "Active Vibration Control of Rotor-Bearing System. PhD Thesis", University of Melbourn, Melbourn (1995).

[4] Bai C., Zhang H., Xu Q. "Experimental and numerical studies on nonlinear dynamic behavior of rotor system supported by ball bearings", Journal of Engineering for Gas Turbine and Power, 132(8) (2010): 082502. DOI:10.1115/1.4000586.

[5] Xia Z., Qiao G., Zheng T., Zhang W., "Nonlinear modelling and dynamic analysis of the rotor-bearing system" , Nonlinear Dynamics, 57(4) (2009): 559-577. DOI: 10.1007/s11071-008-9442-3.

[6] Harris T.A., Rolling Bearing Analysis (John Wiley \& Sons, Inc., 2001).

[7] David P.F., Poplawski J.V., "Transient vibration prediction for rotors on ball bearings using load-dependent non-linear bearing stiffness", International Journal of Rotating Machinery, 10(6) (2002): 489-494. DOI: 10.1080/10236210490504102.

[8] Yamamoto T., Ishida Y., "Transient vibration prediction for rotors on ball bearings using load-dependent non-linear bearing stiffness", International Journal of Rotating Machinery, 10(6) (2002): 489-494. DOI: 10.1080/10236210490504102.

[9] Changsen W., Analysis of rolling element bearings (Mechanical Engineering Publications Limited, 1991).

[10] Kel'zon A.S., Zhuravlev Yu.N., YAnvarev N.V., Raschet $i$ konstruirovanie rotornyh mashin /Calculation and design of rotary machines] (L.: Mashinostroenie, 1977): 288.

[11] Kydyrbekuly A., Khajiyeva, L., Gulama-Garyp A.Y., Kaplunov J., "Nonlinear Vibrations of a Rotor-Fluid-Foundation System Supported by Rolling Bearings", Strojniski Vestnik/Journal of Mechanical Engineering 62(6) (2016): 351-362.

[12] Kydyrbekuly A., Ibrayev G., Ospan T., Nikonov A., "Multi-parametric Dynamic Analysis of a Rolling Bearings System" , Strojniski Vestnik/Journal of Mechanical Engineering 67(9) (2021): 421-432.

[13] Jin Y., Lu Z., Yang R., Hou L., Chen Y. "A new nonlinear force model to replace the Hertzian contact model in a rigid-rotor ball bearing system", Applied Mathematics and Mechanics 39(3) (2018): 365-378. 